\title{
Еволюція концептуальних підходів у дослідженні понятійно-змістового трактування сутності органічного землеробства
}

\author{
Орехівський В.Д., Національна наукова сільськогосподарська бібліотека \\ Національної академії аграрних наук України
}

На основі іноземних та вітчизняних наукових досліджень проаналізовані існуючі термінологічні визначення органічного землеробства. 3'ясовано спільні ознаки розглянутих трактувань щодо органічного землеробства, органічного виробництва, органічного сільського господарства та органічної продукції. Запропоновано авторське бачення змісту органічного землеробства, яке включає застосування системи дієвих природних заходів, що сприяють підвищенню родючості грунту, оптимальному росту сільськогосподарських культур та отриманню екологічно чистої продукції. Визначено, що органічне землеробство базується на використанні науково обгрунтованої структури посівних площ і спеціалізованих сівозмін із вирощуванням багаторічних бобових трав, застосуванні мілкого безполицевого обробітку грунту, використанні сидеральних культур на зелене добриво, внесенні науково обгрунтованих норм органічних добрив, запровадженні екологічно безпечних агротехнічних та біологічних заходів у технологіях вирощування сільськогосподарських культур. Встановлено, що в органічному землеробстві виключається використання синтетичних хімікатів (мінеральні добрива, пестициди, антибіотики тощо) та генетично модифікованих організмів.

Ключові слова: альтернативне землеробство; органічне виробництво; науково обгрунтовані сівозміни; органічні добрива; екологічно чиста продукція

\section{An evolution of conceptual approaches is in research of concept-semantic interpretation of essence of organic agriculture}

\section{Orekhivskyi V. D., National Scientific Agricultural Library of the National Academy of Agricultural Sciences of Ukraine}

It is set that in the second half of XX of century intensive application of mechanization with her harmful influence on the structure of soil, chemistry, irrigation, scientific selection, including creation of genetically modified sorts of agricultural cultures, allowed to go out on the new level of development of agriculture that provided decision of food problem in Ukraine. At the same time negative influence of the marked factors of intensification on a natural environment developed becoming of the new going near a menage in an agrarian sphere, that were incarnated in the input of organic agriculture. Application of rational land-tenure, that is based on principles of organic agriculture and provides proceeding in the natural state of environment, became actual, and agriculture complements a natural constituent with the aim of production ecologically of safe products.

Working of world and home terminological features of understanding of essence of organic agriculture, differences of his interpretation became a research aim in international and state legislative and normative documents with the selection of advantages of him conceptual approaches.

Certainly, that organic agriculture presents the integral multifunction model of menage and production of organic goods that provides the balanced dynamic equilibrium between the components of the ecological, economic and sociological systems during the certain interval of time with the aim of association of the economy growing and increase of standard of life with the simultaneous improvement of the state of environment. Authorial vision of maintenance of organic agriculture, that includes application of the system of effective natural measures, that assist the fertility-improving of soil, optimal height of agricultural cultures and receipt ecologically of clean products, is offered. It is found out, that organic agriculture is based on the use of scientifically reasonable structure of sowing areas and specialized crop rotations with till of long-term leguminous herbares, application of shallow till of soil without shelves, use of siderations cultures on a green fertilizer, bringing of scientifically reasonable norms of organic fertilizers, input ecologically of safe agrotechnical and biological measures in technologies of growing of agricultural cultures. It is set that the use of synthetic mineral fertilizers, pesticides, antibiotics and genetically modified organisms is eliminated in organic agriculture.

Keywords: alternative agriculture; organic production; scientifically reasonable crop rotations; organic fertilizers; ecologically clean products 


\section{Эволюция концептуальных подходов в исследовании понятийно- смысловой трактовки сущности органического земледелия}

\section{Ореховский В.Д., Национальная научная сельскохозяйственная библиотека Национальной академии аграрных наук Украины}

На основании иностранных и отечественных научных исследований проанализированы существующие терминологические определения органического земледелия. Выяснены общие признаки рассмотренных толкований относительно органического земледелия, органического производства, органического сельского хозяйства и органической продукции. Предложено авторское виденье содержания органического земледелия, которое включает применение системы действенных естественных мероприятий, которые способствуют повышению плодородия почвы, оптимальному росту сельскохозяйственных культур и получению экологически чистой продукции. Определено, что органическое земледелие базируется на использовании научно обоснованной структуры посевных площадей и специализированных севооборотов с выращиванием многолетних бобовых трав, применении мелкой безотвальной обработки почвы, использовании сидеральных культур на зеленое удобрение, внесении научно обоснованных норм органических удобрений, вводе экологически безопасных агротехнических и биологических мероприятий в технологиях выращивания сельскохозяйственных культур. Установлено, что в органическом земледелии исключается использование синтетических химикатов (минеральные удобрения, пестициды, антибиотики и тому подобное) и генетически модифицированных организмов.

Ключевые слова: альтернативное земледелие; органическое производство; научно обоснованные севообороты; органические удобрения; экологически чистая продукция

\section{Постановка проблеми.}

$\mathrm{Y}$ другій половині XX ст. інтенсивне застосування механізації з іiї шкідливим впливом на структуру грунту, хімізації, зрошення, наукової селекції, у тому числі створення генетично модифікованих сортів сільськогосподарських культур, дозволили вийти на новий рівень розвитку сільського господарства, що забезпечило вирішення продовольчої проблеми в Україні. Водночас негативний вплив зазначених чинників інтенсифікації на навколишнє природне середовище розвинув становлення нових підходів до господарювання в аграрній сфері, які втілилися у запровадженні органічного землеробства. Актуальним стало застосування раціонального землекористування, яке базується на принципах органічного землеробства та забезпечує відновлення природного стану навколишнього середовища, a сільське господарство доповнює природною складовою з метою виробництва екологічно безпечної продукції.

\section{Аналіз досліджень і публікацій.}

Трактуванню сутності поняття «органічне землеробство» у літературних джерелах приділено велику увагу, оскільки підходів до визначення відповідної дефініції та ії напрямів представлено значну кількість. У більшості наукових досліджень поняття «органічне землеробство», «органічне виробництво», «органічне сільське господарство», «органічна продукція» визначено як рівнозначні $[1-4 ; 7-8 ; 15 ; 18-20]$. Крім того, трактування сутності «органічних» понять поставали при ухваленні законів, стандартів, постанов тощо [5-6; 9-10; 13-14; 16; 23; 25]. Зважаючи на те, що сільське господарство вже включає в себе землеробство та виробництво продукції, варто розглядати ці категорії як єдине ціле.

\section{Мета дослідження.}

Опрацювання світових і вітчизняних термінологічних особливостей розуміння сутності органічного землеробства, відмінностей його трактування у міжнародних та державних законодавчих і нормативних документах із виділенням переваг його концептуальних підходів.

\section{Виклад основного матеріалу.}

Вперше аграрне виробництво як окремий напрям, що грунтується на використанні виключно власних добрив та кормів, визначено австрійським природознавцем Р. Штайнером як біодинамічне землеробство [12, с. 17]. У 1924 р. він представив свою концепцію, яка полягала у біодинамічній інтерпретації природи, в якій підкреслювався тісний взаємозв'язок у системі «земля - людина - космос» [26, с. 5]. У 1940 р. вперше термін «органічне землеробство» використав Л. Нортборн у книзі «Погляд на землю» [24]. Цей термін підтримав та продовжив застосовувати британський вчений А. Говард у книзі «Грунт та здоров'я. Дослідження органічного сільського господарства», описуючи негативну дію хімічних засобів та антибіотиків на здоров'я рослин і тварин [22]. У 1945 р. в США засновник журналу «Органічне фермерство і садівництво» Ж. Родейл одним із перших популяризував новий підхід до виробництва ор- 
ганічної продукції [12, с. 17]. На початку 1960-х років протест проти забруднення навколишнього середовища, використання великої кількості консервантів у продуктах харчування, надмірної хімізації аграрного виробництва, що поставило під загрозу якість умов життя населення, знайшов своє втілення у поширенні ідеї органічного землеробства.

Термін «органічне землеробство» (Organic Farming) запроваджений Міжнародною федерацією «Рух за органічне сільське господарство» (IFOAM), заснованою у 1972 р., яка на сьогодні об'єднує понад 750 організацій у 116 країнах світу [11, с. 393]. Воно загальноприйняте в термінології англомовних країн $Є С$ та США і означає такий спосіб сільськогосподарського виробництва, за якого виключається використання синтетичних хімікатів (добрив, пестицидів, антибіотиків тощо) та генетично модифікованих організмів для одержання екологічно чистої продукції [27].

Згідно 3 тлумачним словником, термін «органічний» означає «живий організм», тобто пов’язаний із життям [21, с. 479]. Світова практика органічного землеробства базується на комплексі принципів та правил раціонального використання природних ресурсів у процесі вирощування сільськогосподарських культур і тісно пов'язана зі вживанням терміну «гармонійний» [19, с. 13]. Адже органічне землеробство не тільки забезпечує споживчий ринок натуральними продуктами 3 їх оздоровчими властивостями, а й сприяє відновленню навколишнього природного середовища.

У 1980 р. Департамент сільського господарства USDA запропонував таке визначення органічного землеробства - система виробництва сільськогосподарської продукції, яка забороняє або значною мірою обмежує використання синтетичних комбінованих добрив, пестицидів та регуляторів росту сільськогосподарських культур. Така система максимально базується на використанні сівозмін, рослинних решток, гною та компостів, бобових рослин та рослинних добрив, органічних відходів виробництва, мінеральної сировини, механічному обробітку грунту та біологічних заходах боротьби зі шкідниками з метою підвищення родючості та покращання структури грунту, забезпечення повноцінного живлення рослин і боротьби з різноманітними бур'янами, шкідниками та хворобами сільськогосподарських культур [25, с. 102].

У 1980 р. Франція стала першою країною в Європі, яка ухвалила національне законодавство щодо органічного землеробства. Перший законодавчий стандарт, що регулював органічне земле- робство, ухвалено в Австрії у 1985 р. [12, с. 17]. Згодом вони були затверджені в інших країнах, що сприяло ухваленню у 1991 р. постанови Ради ЄC та забезпечило впровадження спільного загальноєвропейського законодавства. Згідно 3 постановою Ради ЄС органічне землеробство із застосуванням лише органічних добрив передбачає таку систему господарювання, де вирощування сільськогосподарських культур здійснюють без використання синтетичних добрив, пестицидів та стимуляторів росту [5].

Комісія ЄС для узгодженості термінологічних відмінностей органічного землеробства визначила його еквіваленти для різних країн. Зокрема, термін «органічне землеробство» (Organic Farming) офіційно прийнятий в англомовних країнах $\mathrm{E}_{\text {в- }}$ ропейського Союзу та США [7, с. 346]. Еквівалентним терміном у Греції, Італії, Португалії, Франції та країнах Бенілюксу є «біологічне землеробство» (Biological Farming). У Данії, Естонії, Литві, Німеччині, Польщі, Румунії, Словенії, Угорщині та іспаномовних країнах використовують термін «екологічне землеробство» (Ecological Farming); Австрії - «біодинамічне землеробство (Biodynamic Farming); Швеціï, Швейцарії - «органічно-біологічне землеробство» (OrganicBiological Farming) [8, с. 96]. Різниця між ними не завжди має чіткий зміст і термінологічний характер, але основою всіх зазначених напрямів $є$ застосування у землеробстві безпечних природних заходів для виробництва корисної продукції. Крім того, у постанові Ради $Є С$ на базі «Основ критеріїв екологічного (органічного) землеробства» надано законну силу трьом поняттям як синонімам: екологічне $=$ органічне $=$ біологічне землеробство $[4$, c. 115$]$. Тому терміни «органічний», «екологічний», «біологічний» тощо потрібно використовувати як синоніми.

У 1995 р. в США Колегія національних стандартів органічної продукції USDA запропонувала органічне землеробство визначати як систему екологічного менеджменту сільськогосподарського виробництва, що підтримує та покращує біорізноманіття, біологічні цикли та біологічну активність грунтів. Вона базується на мінімальному використанні неприродних (штучних) сировини та матеріалів і агротехнічних заходах, які відроджують, підтримують та покращують екологічну гармонію [23]. Згідно з цим визначенням, керівним принципом для впровадження органічного землеробства стало використання матеріалів і технологій, які покращують екологічну рівновагу та сприяють створенню стійких і збалансованих агроекоси- 
стем [1, с. 12]. Основний акцент було зосереджено на досягненні екологічного балансу між грунтовою фауною, тваринним світом та людським суспільством [13]. Подібне трактування визначене в «Кодексі Аліментаріус», згідно якого органічне землеробство - це система управління виробництвом, яка дозволяє підтримувати та покращувати санітарний стан агроекосистеми, в тому числі біорізноманіття, біологічний кругообіг і біологічну активність грунту [9].

У 2007 р. у постанові Ради ЄС щодо органічного виробництва та маркування органічної продукції вказано, що органічне землеробство - це цілісна система господарювання, яка поєднує збереження довкілля, природних ресурсів і біологічного різноманіття, застосування стандартів належного виробництва, які відповідають певним вимогам до продукції, виготовленої з використанням речовин природного походження [16]. Аналогічне визначення органічного землеробства у 2010 p. запропонувала Федерація органічного руху України у Концепції державної програми розвитку органічного виробництва [10]. Таке трактування дає підстави стверджувати, що застосування органічного землеробства має екологічне (створює загальне благо, сприяючи захисту довкілля та зрівноваженому розвитку сільських територій) i економічне значення (забезпечує специфічний продовольчий ринок, який відповідає зростаючим потребам споживачів органічної продукції).

Наукові засади органічного землеробства у 2008 p. викладені в основних положеннях Міжнародної федерації органічного сільськогосподарського руху IFOAM. За iï визначенням, органічне землеробство об'єднує всі сільськогосподарські системи, які підтримують екологічно, соціально та економічно доцільне виробництво сільськогосподарської продукції. В основі таких систем лежить використання локально-специфічної родючості грунтів як ключового елементу успішного виробництва. Такі системи використовують природний потенціал рослин, тварин та ландшафтів і спрямовані на гармонізацію сільськогосподарської практики та навколишнього середовища [14]. Воно залежить від екологічних процесів, біологічної різноманітності та природних циклів, характерних для місцевих умов. При цьому уникають використання шкідливих ресурсів, які викликають несприятливі наслідки. Органічне землеробство поєднує в собі традиції, нововведення та наукові інновації з метою покращання стану навколишнього природного середовища та сприяє розвитку справедливих взаємовідносин і належного рівня життя.
В Україні основним документом, що визначає правові, економічні та соціальні основи ведення органічного землеробства $€$ Закон України «Про виробництво та обіг органічної сільськогосподарської продукції та сировини» від 12 лютого 2015 p. [6]. У документі передбачено чітке визначення терміну «органічне землеробство» як системи ведення сільського господарства, що полягає у максимальному залученні для мінерального живлення рослин відновлюваних місцевих органічних ресурсів (гною, побічної продукції рослинництва, сидератів тощо), біопрепаратів удобрювальної і захисної дії, органо-мінеральних та біоактивних добрив із застосуванням екологосумісних агрохімікатів природного походження у довгоротаційних і короткоротаційних сівозмінах.

Таким чином, у нормативно-правовому розумінні основним критерієм у визначенні органічного землеробства є відповідність певним, законодавчо закріпленим правилам виробництва органічної продукції. Під терміном «органічне землеробство» розуміють сільськогосподарське виробництво з виключно органічної сировини без застосування хімічних добрив, пестицидів та генетично модифікованих організмів.

На основі узагальнення наукових досліджень можна зробити висновок, що більшість українських вчених термін «органічне землеробство» асоціює 3 термінами «органічне виробництво», «органічне сільське господарство», «органічна продукція». Зокрема, О. А. Томашевська акцентує увагу на тому, що згідно зі світовими стандартами органічним вважається землеробство, в якому не використовують хімікати, не застосовують генетично модифіковані організми та яке передбачає мінімальний обробіток грунту $[17$, с. 162]. У трактуванні Г. Д. Гуменюка органічне землеробство означає цілісний системний підхід, що базується на сукупності методів, які забезпечують життєздатну екосистему, безпечне продовольство, корисне харчування та соціальну справедливість [2, с. 13]. Цінною є думка А. В. Вдовиченка, В. А. Чудовської, О. І. Шкуратова, які вважають, що органічне землеробство за своєю суттю можна визначити як цілісну систему управління агроекосистемами, що включає оцінку потенційних екологічних і соціальних ризиків та встановлює порядок взаємовідносин економічних суб'єктів у процесі виробництва органічної продукції [20, c. 70]. Важливим є твердження М. М. Федорова, О. В. Ходаківської, С. Г. Корчинської, які, поділяючи підхід міжнародних організацій до визначення «органічне виробництво», акцентують увагу на 
виключній важливості традицій, клімату та місцевих історико-культурних особливостей у відродженні органічного землеробства. Вони зазначають, що органічне землеробство грунтується на принципах, які зумовлені місцевими соціально-економічними, кліматичними та історико-культурними особливостями, серед яких досить складно виявити пріоритетні, оскільки вони однаковою мірою важливі $[18$, с. 6$]$.

Органічне землеробство як складну екологічно збалансовану систему сільськогосподарського виробництва розглядає О. Т. Дудар. Він вважає, що іiі ключовими завданнями $є$ ефективне виробництво натуральної продукції, що має біологічно цінні якості й оздоровчі властивості для забезпечення повноцінного харчування людей і виключає будь-які ризики для здоров'я та сприяє збереженню навколишнього природного середовища [3, с. 122]. За визначенням Ю. С. Голіка, О. О. Горба, Т. В. Невмиваки, П. В. Писаренка під терміном «органічне землеробство» розуміють сільськогосподарське виробництво, за якого не використовують синтетичні хімікати (добрива, пестициди, антибіотики тощо), здійснюють мінімальний обробіток грунту і не застосовують генетично модифіковані організми $[15$, с. 120]. Як вважає Т. О. Зайчук, за своєю суттю воно $є$ багатофункціональною агроекологічною моделлю виробництва, базується на ретельному плануванні та управлінні агроекосистемами, що дозволяє у перспективі узгодити і гармонізувати екологічні, економічні та соціальні чинники $[4$, с. 115]. Вченими запропоновано визначення «органічного землеробства» як системи сільськогосподарського менеджменту агроекосистем, що грунтується на максимальному використанні біологічних чинників підвищення родючості грунту, агротехнічних і біологічних заходів захисту рослин, а також комплексі інших заходів, які забезпечують екологічно, економічно та соціально доцільне виробництво сільськогосподарської продукції [4, с. 116].

Аналізуючи світові та вітчизняні напрацювання трактувань сутності органічного землеробства та його складових, необхідно зазначити вирізнення багатьох його спільних ознак. У більшості наукових праць органічне землеробство грунтується на принципах здоров'я, екології, справедливості та турботи і узгоджується із законами природи. Найбільш вдалим є трактування Т. О. Чайки, згідно якого «органічне землеробство» представляе цілісну багатофункціональну модель господарювання та виробництва органічної продукції, яка забезпечує збалансовану динамічну рівновагу між компонентами інтегрованої еколого-економіко-соціологічної системи упродовж визначеного проміжку часу з метою об'єднання економічного зростання та підвищення життєвого рівня з одночасним поліпшенням стану навколишнього середовища $[19$, с. 15].

В органічному землеробстві потрібно застосовувати систему дієвих природних заходів, що сприятиме підвищенню родючості грунту, оптимальному росту сільськогосподарських культур та отриманню екологічно чистої продукції. Важливим є використання науково обгрунтованої структури посівних площ і спеціалізованих сівозмін із вирощуванням багаторічних бобових трав, застосування мілкого безполицевого обробітку грунту, використання сидеральних культур на зелене добриво, внесення науково обгрунтованих норм органічних добрив, запровадження екологічно безпечних агротехнічних та біологічних заходів у технологіях вирощування сільськогосподарських культур.

\section{Висновки.}

Аналіз сучасних світових та вітчизняних підходів до становлення і розвитку органічного землеробства дозволяє стверджувати про наявність стійкої тенденції до поглиблення та удосконалення трактування його сутності. Його еволюція відбувається у поєднанні мети, методів, обмежень, технологій, відповідного комплексу заходів, стадій процесів виробництва та необхідності забезпечення населення якісними продуктами харчування. Практичне застосування органічного землеробства виконує екологічну, економічну та соціальну функції.

У міжнародному науковому співтоваристві отримало визнання трактування органічного землеробства як системи управління виробництвом, що забезпечує рівновагу між продуктивністю агроекосистеми і відновленням навколишнього середовища, а також забезпечує інтегровану сталість антропогенних екосистем у відповідності до концепції збалансованого розвитку.

\section{БІБІЛІОГРАФІЧНІ ПОСИЛАННЯ}

1. Гармашов В. В. До питання органічного сільськогосподарського виробництва в Україні / В. В. Гармашов, О. В. Фомічова // Вісник аграрної науки. - 2010. - № 7. - С. 11-16.

2. Гуменюк Г. Д. Вимоги міжнародних стандартів щодо сертифікації органічного виробництва та акредитації органів, які іiі здійснюють / Г. Д. Гуменюк // Стандартизація, сертифікація, якість. - 2012. - № 4. - С. 13-18. 
3. Дудар О. Т. Розвиток органічного агровиробництва в Україні / О. Т. Дудар // Економіка АПК. - 2012. - № 3. - С. 121-126. 4. Зайчук Т. О. Вітчизняний ринок екологічно чистих продуктів харчування та шляхи його розвитку / Т. О. Зайчук // Економіка і прогнозування. - 2009. - № 4. - С. 114-125.

5. Заключний звіт «Розвиток органічного агровиробництва в Україні». - Режим доступу: http://www.bdmta.org.ua/ta/ files/200909151711210.FinalReport\%200727\%20Ukr.doc.

6. Про виробництво та обіг органічної сільськогосподарської продукції та сировини: Закон України №191-VIII від 12 лютого 2015 p. - Режим доступу: http://zakon4.rada.gov.ua/laws/show/425-18

7. Коваленко Н. П. Екологічно збалансовані сівозміни в системі альтернативного землеробства: історичні аспекти / Н. П. Коваленко // Агроекологічний журнал. - 2012. - № 4. - С. 95-99.

8. Коваленко Н. П. Становлення та розвиток науково-організаційних основ застосування вітчизняних сівозмін у системах землеробства (друга половина XIX - початок XXI ст.) / Н. П. Коваленко. - Київ: ТОВ «Нілан-ЛТД», 2014. - 490 с.

9. Кодекс Алиментариус. Органические пищевые продукты. - М.: Весь Мир, 2006. - 72 с.

10. Концепція державної програми розвитку органічного виробництва в Україні. - Режим доступу: http://www.organic.com.ua/ uk/homepage/2010-01-26-13-45-25?start=7

11. Кутаренко Н. Я. Проблема понятійно-змістового трактування сутності органічного агровиробництва / Н. Я. Кутаренко // Науковий вісник Буковинського державного фінансово-економічного університету. Економічні науки. - 2014. - № 27. - С. 391-397.

12. Мінькова О. Г. Сучасні тенденції у становленні принципів органічного сільського господарства / О. Г. Мінькова // Вісник Уманського національного університету садівництва. - 2015. - № 1. - С. 16-21.

13. Офіційний сайт Agricultural Marketing Service. - Режим доступу: http://www.ams.usda.gov

14. Офіційний сайт Міжнародної Федерації органічного сільськогосподарського руху. - Режим доступу: http://www.ifoam.bio/ sites/default/files/page/files/doa_ukranian.pdf

15. Писаренко П. В. Основи біологічного та адаптивного землеробства / П. В. Писаренко, О. О. Горб, Т. В. Невмивака, Ю. С. Голік. - Полтава, 2009. - 312 с.

16. Постанова Ради ЄС №834/2007 стосовно органічного виробництва і маркування органічних продуктів від 28 червня 2007 p. - Режим доступу: http://organicstandard.com.ua/files/standards/ua/ec. (дата звернення: 25.04.2018).

17. Томашевська О. А. Органічне виробництво в світі: реалії та перспективи / О. А. Томашевська // Інноваційна економіка. 2013. - № 6. - С. 161-164.

18. Федоров М. М. Розвиток органічного виробництва / М. М. Федоров, О. В. Ходаківська, С. Г. Корчинська. - Київ: ННЦ IAE, 2011. $-146 \mathrm{c}$.

19. Чайка Т. О. Розвиток виробництва органічної продукції в аграрному секторі економіки України / Т. О. Чайка. - Донецьк: Ноулідж, 2013. - 320 с.

20. Шкуратов О. І. Органічне сільське господарство: екологічні імперативи розвитку / О. І. Шкуратов, В. А. Чудовська, А. В. Вдовиченко. - Київ, 2015. - 285 с.

21. Яременко В. В. Новий тлумачний словник української мови / В. В. Яременко, О. М. Сліпушко. - Київ: Аконіт, 2005. - Т. 2. - 928 с. 22. Howard A. The Soil and Health. A Study of Organic Agriculture. - USA: The University Press of Kentucky, 2007. - 356 p.

23. National Organic Standard Board Recommendations (National Organic Program USDA). - Retrieved from: http://www.ams.usda. gov/nop/nosbinfo.htm

24. Northbourn L. Look to the Land / L. Northbourn. - Sophia Perenniset Universalis, 2003. - 128 p.

25. Report and recommendations on organic farming. Prepared by USDA. Study Team on Organic Farming. - Retrieved from: http:// www.nal.usda.gov/afsic/pubs/USDAOrgFarmRpt.pdf

26. Rowalska A. The quality and competitiveness in ecological agriculture / A. Rowalska. - Warszawa: Difin SA, 2010. - 295 p.

27. Scialabba N. Organic agriculture, environment and food security / N. Scialabba, C. Hattam. - Rome: FAO, 2002. - 252 p.

\section{REFERENCES}

1. Harmashov, V.V., \& Fomichova, O.V. (2010). Do pytannia orhanichnoho silskohospodarskoho vyrobnytstva v Ukraini [To the question of organic agricultural production in Ukraine]. Visnyk ahrarnoi nauky, 7, 11-16 [in Ukrainian].

2. Humeniuk, H.D. (2012). Vymohy mizhnarodnykh standartiv shchodo sertyfikatsii orhanichnoho vyrobnytstva ta akredytatsii orhaniv, yaki yii zdiisniuiut [Requirements of international standards in relation to the certification of organic production and accreditations of organs, that carry out her]. Standartyzatsiia, sertyfikatsiia, yakist, 4, 13-18 [in Ukrainian].

3. Dudar, O.T. (2012). Rozvytok orhanichnoho ahrovyrobnytstva v Ukraini [Development of organic agricultural production is in Ukraine]. Ekonomika APK, 3, 121-126 [in Ukrainian].

4. Zaichuk, T.O. (2009). Vitchyznianyi rynok ekolohichno chystykh produktiv kharchuvannia ta shliakhy yoho rozvytku [Home market ecologically clean foodstuffs and ways of his development]. Ekonomika i prohnozuvannia, 4, 114-125 [in Ukrainian].

5. Zakliuchnyi zvit «Rozvytok orhanichnoho ahrovyrobnytstva $v$ Ukraini» [The final report «Development of organic agricultural production in Ukraine»]. Retrieved from: http://www.bdmta.org.ua/ta/files/200909151711210.FinalReport\%200727\%20Ukr.doc [in Ukrainian].

6. Pro vyrobnytstvo ta obih orhanichnoi silskohospodarskoi produktsii ta syrovyny: Zakon Ukrainy №191-VIII vid 12 liutoho 2015 r. [Law of Ukraine No191-VIII «On the production and circulation of organic agricultural products and raw materials» from 12.02.2015]. Retrieved from: http://zakon4.rada.gov.ua/laws/show/425-18 [in Ukrainian].

7. Kovalenko, N.P. (2012). Ekolohichno zbalansovani sivozminy v systemi alternatyvnoho zemlerobstva: istorychni aspekty [Ecologically balanced crop rotations in the system of alternative agriculture: historical aspects]. Ahroekolohichnyi zhurnal, 4, 95-99 [in Ukrainian].

8. Kovalenko, N.P. (2014). Stanovlennya ta rozvytok naukovo-orhanizatsiynykh osnov zastosuvannya vitchyznyanykh sivozmin $u$ systemakh zemlerobstva (druha polovyna XIX - pochatok XXI st.) [The becoming and development of scientifically-organizational bases of application of home crop rotations in the systems of agriculture (the second half of XIX is beginning of XXI of century)]. Kyiv: TOV «Nilan-LTD» [in Ukrainian]. 
9. Kodeks Alymentaryus. Orhanycheskye pyshchevye produkty [Codex Alimentarius. Organically Produced Foods.]. (2006). Moscow: Ves Myr [in Russian].

10. Kontseptsiia derzhavnoi prohramy rozvytku orhanichnoho vyrobnytstva $v$ Ukraini [Conception of the government program of development of organic production is in Ukraine]. Retrieved from: http://www.organic.com.ua/uk/homepage/2010-01-26-13-4525? start $=7$ [in Ukrainian].

11. Kutarenko, N.Ya. (2014). Problema poniatiino-zmistovoho traktuvannia sutnosti orhanichnoho ahrovyrobnytstva [The problem of conceptual-semantic interpretation of theessence of organic agricultural production]. Naukovyi visnyk Bukovynskoho derzhavnoho finansovo-ekonomichnoho universytetu. Ekonomichni nauky, 27, 391-397 [in Ukrainian].

12. Minkova, O.H. (2015). Suchasni tendentsii u stanovlenni pryntsypiv orhanichnoho silskoho hospodarstva. [Modern tendencies are in becoming of principles of organic agriculture]. Visnyk Umanskoho natsionalnoho universytetu sadivnytstva, 1, 16-21 [in Ukrainian]. 13. The official website for Agricultural Marketing Service. Retrieved from: http://www.ams.usda.gov

14. The official website of the International Federation of Organic Agriculture Movements. Retrieved from: http://www.ifoam.bio/sites/ default/files/page/files/doa_ukranian.pdf

15. Pysarenko, P.V., Horb, O.O., Nevmyvaka, T.V., \& Holik, Yu.S. (2009). Osnovy biolohichnoho ta adaptyvnoho zemlerobstva: navchalnyi posibnyk. [Bases of biological and adaptive agriculture: train aid]. Poltava [in Ukrainian].

16. Postanova Rady IeS №834/2007 stosovno orhanichnoho vyrobnytstva i markuvannia orhanichnykh produktiv vid 28 chervnia 2007 r. [Council Regulation EC No 834/2007 on organic production and labelling of organic products of 28.06.2007]. Retrieved from: http://organicstandard.com.ua/files/standards/ua/ec [in Ukrainian].

17. Tomashevska, O.A. (2013). Orhanichne vyrobnytstvo v sviti: realii ta perspektyvy [Organic production in the world: realities and prospects]. Innovatsiina ekonomika, 6, 161-164 [in Ukrainian].

18. Fedorov, M.M., Khodakivska, O.V., \& Korchynska, S.H. (2011). Rozvytok orhanichnoho vyrobnytstva [Development of organic production]. Kyiv: NNTs IAE [in Ukrainian].

19. Chaika, T.O. (2013). Rozvytok vyrobnytstva orhanichnoi produktsii v ahrarnomu sektori ekonomiky Ukrainy [The development of organic production in the agricultural sector of Ukraine]. Donetsk: Noulidzh [in Ukrainian].

20. Shkuratov, O.I., Chudovska, V.A., \& Vdovychenko, A.V. (2015). Orhanichne silske hospodarstvo: ekolohichni imperatyvy rozvytku [Organic agriculture: ecological imperatives of development: monograph]. Kyiv [in Ukrainian].

21. Yaremenko, V.V., \& Slipushko, O.M. (2005). Novyi tlumachnyi slovnyk ukrainskoi movy. [New explanatory dictionary of Ukrainian]. (Vols. 2). Kyiv: Akonit [in Ukrainian].

22. Howard, A. (2007). The Soil and Health. A Study of Organic Agriculture. The University Press of Kentucky.

23. National Organic Standard Board Recommendations (National Organic Program USDA). Retrieved from: http://www.ams.usda. gov/nop/nosbinfo.htm

24. Northbourn, L. (2003). Look to the Land. Sophia Perenniset Universalis.

25. Report and recommendations on organic farming. Prepared by USDA. Study Team on Organic Farming. (1980). Retrieved from: http://www.nal.usda.gov/afsic/pubs/USDAOrgFarmRpt.pdf

26. Rowalska, A. (2010). The quality and competitiveness in ecological agriculture. Warszawa: Difin SA [in Polish].

27. Scialabba, N., \& Hattam, C. (2002). Organic agriculture, environment and food security. Rome: FAO.

\title{
Орехівський Володимир Данилович
}

Кандидат технічних наук

Національна наукова сільськогосподарська бібліотека Національної академії аграрних наук України 03127, м. Київ, вул. Героїв оборони, 10

\section{Orekhivskyi Volodymyr}

Candidate of Engineering Sciences

National Scientific Agricultural Library of the National Academy of Agricultural Sciences of Ukraine 10, Geroiv Oborony St., Kyiv, 03127, Ukraine

\author{
ORCID: 0000-0002-3216-0514Ｅmail: Orekhovskiy@gmail.com
}

Цитування: Орехівський В. Д. Еволюція концептуальних підходів у дослідженні понятійно-змістового трактування сутності органічного землеробства / В. Д. Орехівський // Науково-теоретичний альманах «Грані». - 2018. - Т. 21. - № 5. - С. 90-96.

Citation: Trohaniak, A.S. (2018). Stan, tendentsii ta naukovi zasady sotsialno-ekolohichnykh problem suspilstva [Status, tendencies and scientific principles of socio-environmental problems of society]. Scientific and theoretical almanac «Grani», 21(5), 90-96. 